\title{
EXTERNAL ECONOMIC SECURITY OF UKRAINE: CONDITIONS, PROBLEMS AND PROSPECTS
}

\author{
Irina Babets ${ }^{1}$, Mariya Fleychuk ${ }^{2}$ \\ ${ }^{1}$ Doctor of Economic, Asociate professor, Zaporizhzhya Institute of Economics and Information Technology, \\ 6b, Kiyashko St., c. Zaporizhzhya, 69015, Ukraine. \\ Phonenumber+380500599734,Email address irina.babets@ukr.net, \\ ${ }^{2}$ Professor, Lviv University of Trade and Economics, 10, Tuhan-Baranovskyi Str., 79008, Lviv, Ukraine, Email \\ addressfleychukm@gmail.com
}

Received 2712 2019; Accepted 31082020

In the article the main problems of external security of Ukraine is considered. The strategic vectors of the problems stated above offered. There were used Granger cuasility test, 2 least squares method (regression analises), main components methods. Authors have proved that sharp fluctuations in the most important factors of Ukraine's foreign economic security in the short-term lags indicate threatening trends associated with increasing technological and export dependence of the state, which is a consequence of low competitiveness in both domestic and foreign markets and inefficient economic structure.

Key words: external economic security, Ukraine, international economic relations.

JEL codes: EO24; F11.

\section{Introduction}

The current state of globalization creates new opportunities and unlimited means for development. However, the globalization of world economic relations has resulted in the cultivation of new challenges and threats to the security of individual states. This is manifested in the state of economic relations with major partners. Thus, there is a direct relationship between the foreign economic component of national security and international economic security, which is manifested in changes in the dynamics of macroeconomic indicators of foreign trade. The level of Ukrainian economy integration security the into world economic relations is influenced by the country's ability to resolve conflict situations related to the need to comply with the requirements of international agreements, while ensuring the protection of national interests.

Recently, global competition for spheres of influence, including in the post-Soviet space, has intensified. Despite its non-aligned status, Ukraine is increasingly facing conflict situations on the part of the most influential states, primarily the Russian Federation. This exacerbates the destructive impact of internal threats associated with socio-economic and political transformations in Ukraine. An obvious danger in the geopolitical context for Ukraine is Russia's foreign policy, which, according to some researchers, is an attempt to increase geopolitical pressure in the post-Soviet space, which contradicts the European integration aspirations of Ukraine and other post-Soviet states (Parahons'kij, 2013).

Copyright (C) 2020. Published by Vytautas Magnus University. This is an open access article distributed under the terms of the Creative Commons Attribution Non-Commercial 4.0 (CC BY-NC 4.0) license, which permits unrestricted use, distribution, and reproduction in any medium provided the original author and source are credited. The material cannot be used for commercial purposes. 
In these conditions, the aggressor cultivated separatist sentiments, which led to the loss of the part of Ukraine's territory and the deepening of the geopolitical crisis. Problems related to the need to strengthen the economic, including external security of Ukraine have become the basis of fundamental developments of such scientists as Baranovs'kij A. (Baranovs'kij, 2014), Vlasiuk O., Ilyash O., Olszewski W. and others (Vlasiuk, 2016).

D. Venckovs'kij singles out the following threats to national economic security in the context of foreign trade cooperation in the terms of real Russian-Ukrainian war: a part of the national economy export potential lossing; exacerbation of the currency crisis; loss of price competitiveness by exporters; non-strategic international commodity specialization; failure of the actual implementation of the EUUkraine Association Agreement (Venckovs'kij, 2015).

In the work of Kozachenko G., Illiashenko O., Matkovskiy A. determines the factors of financial and economic security of domestic business entities and the country as a whole external economic activity. The authors show that the external economic activity with Russia, which is still carried out by domestic enterprises, is a major threat to the Ukraine's economic security in general, and of economic entities including (Kozachenko, 2019).

Kasperovych Y. Consider that the improvement of economic dynamics, based on the restoration of peace in Ukraine, should strengthen the fiscal and national security of the state as a whole to an optimal level. The methodology will be particularly useful during the future de-occupation and reintegration of temporarily uncontrolled territories, restoration of territorial integrity and sovereignty of Ukraine (Kasperovich, 2019).

N. Poida-Nosyk suggests that the Ukrainian government should focus on internal transformations aimed at ensuring the European level of socio-economic development. Only under such conditions it is possible to introduce effective mechanisms aimed at neutralizing the phenomena and factors that become a prerequisite for increasing internal and external threats to the states's financial security (Poida-Nosyk, 2019).

Hypothesis or scientific problem: in the short run, changes in the dynamics of the main factors of Ukraine's foreign economic security indicates the existence of destructive trends, which is a prerequisite for increasing technological and export dependence of the state due to low competitiveness in domestic and foreign markets and inefficient economy on the whole.

The purpose of the paper: the strategic vectors of external economic security vectors of Ukraine strenthenning measured.

The object of the research: process of external economic security vectors strenthenning; the subject external economic sector of Ukraine

The research methods: Granger cuasility test, 2 least squares method (regression analises), main components methods.

The benefits of the research to studies, science and / or business: strategic vectors measuring for economic cooperation with Ukraine for the main partners on macro- and microlevels.

Methods of assessing the level of external economic security of the state.

According to the method of calculating the level of economic security of the state, external economic security is defined as such a state of conformity of external economic activity with national economic interests, which is a prerequisite for minimizing the country's losses under the influence of destructive foreign economic factors and creating competitive advantages (Babets, 2018).

$$
I_{i}=\sum_{J=1}^{m} a_{i j} z_{i j},
$$

where $a_{\mathrm{ij}}$-weighting factors that determine the level of contribution of the $\mathrm{j}$-th component in the integrated index of foreign economic security; $\mathrm{z}_{\mathrm{ij}}$ - normalized input values $\mathrm{x}_{\mathrm{ij}}$. 
The principal components model is used to estimate the weights (ai) (Pro zatverdzhennja, 2007). Normalized values of foreign economic security stimulation factors are calculated as the ratio of the indicator at time $(t)$ to the maximum value of the corresponding indicator for the analyzed period.

The integrated indicator of foreign economic security is equal to 1, provided that all $\mathrm{x}_{\mathrm{ij}}$ reach the "best" or optimal values, and 0 , if all indicators are "worst".

The methodology for calculating the level of national economic security provides a number of external economic security indicators (the share of food imports in domestic consumption; the share of imports in domestic consumption; the ratio of imports (exports) to GDP; the share of raw materials exports in industrial exports; the share of the leading country in total foreign trade) and determines the threshold values of these indicators. The disadvantage of this technique is the lack of indicators that take into account the level of scientific and technological component in international trade. Thus, the analyzed methodology should be supplemented with indicators that allow assessing not only the quantitative parameters of foreign economic activity, in particular: the share of high-tech products in imports (exports); coefficient of technological dependence (the ratio of imports of high-tech goods to the volume of their exports).

Assessing the level of impact of a particular threat on the integrated index of foreign economic security allows you to assess the most dangerous of them and develop measures to neutralize its. The methodology of analysis of dynamic processes in the economic system and calculation of the sensitivity of output indicators to changes in the input parameters of the system, developed by Yu. Kharazishvili (Harazishvili, 2007):

$$
U\left(t, x_{i}\right)=\lim _{\Delta x \rightarrow 0} \frac{y\left(t, x_{i, 0}+\Delta x_{i}\right)-y\left(t, x_{i, 0}\right)}{\Delta x_{i}}=\frac{d y\left(t, x_{i, 0}\right)}{d x_{i, 0}} \approx \frac{\Delta y\left(t, x_{i, 0}\right)}{\Delta x_{i, 0}} .
$$

Estimate (2) allows us to masure the point of elasticity as the limit value of the elasticity of the arc, provided that the increase in the coefficient $x$ is zero. To avoid errors and increase the sensitivity of the integrated index of foreign economic security to the impact of a particular threat, it is important to use the coefficient of elasticity, which allows us to estimate the level of change in function under the influence of argument:

$$
E\left(y_{i, x_{i}}\right)=\frac{\Delta y_{i}}{\Delta x_{i}} \cdot \frac{x_{i}}{y_{i}} .
$$

According to formula (1), the integrated external economic security index $\left(I_{3 E E}\right)$ for the analyzed time interval is a function of a number of indicators $\left(\mathrm{x}_{\mathrm{i}}\right)$ :

$$
I_{3 E B}\left(t, x_{i}\right)=f\left(x_{1}, x_{2}, \ldots, x_{i}\right) \text {. }
$$

The impact of each threat is estimated by the coefficient of elasticity (sensitivity) in year $t$ using the approach described in (Kibitkin, 2010), using the equation:

$$
K_{u}=\frac{\Delta I_{3 E D}}{\Delta x_{i}} \cdot \frac{x_{i}}{I_{3 E B}},
$$

where $\Delta \mathrm{I}_{3 \mathrm{~EB}}$ - the difference between the value of the index after the change of the indicator by $1 \%$ and the current value of the index of external economic security; $\Delta \mathrm{xi}$ - the value of the change in the statistical value of the indicator, \%; $\mathrm{x}_{\mathrm{i}}$ - basic (initial) value of the statistical indicator; IзЕв is the basic value of the integrated index of foreign economic security (Babets, 2018). 


\section{Assessment of Ukraine's external economic security in 2006-2018: state and main factors}

The positive dynamics of individual external economic security indicators, the normalized values of which are presented in Figure 1, indicate the strengthening of the foreign economic security level in the long-term period. Thus, the value of the integrated indicator of foreign economic security increased from 0.71 in 2006 to 0.87 in 2016 . Note that the share of the leading partner country, which still remains $\mathrm{RF}$, in total foreign trade has decreased significantly. The highest value of this indicator (32.4\%), which exceeded the limit criterion of safety, was observed in 2011, and since 2012, it gradually decreased to $11.24 \%$ in 2018. As shown by us in (Babets, 2018) influenced the level of external economic security in 2018 reducing the coefficients of export and import dependence. In the short-term period, there has also been increasing in Ukraine's external economic security from 0.812 in 2017 to 0.861 in 2018 to almost 2016.

At the same time, it should be noted that along with the improvement of compliance with the criteria of economic security of the openness indicators of the Ukrainian economy, over the last three years there has been a significant decreasing in the ratio of coverage of imports by exports, which is due to a faster increase in imports compared to export volumes. Thus, in 2018, exports of Ukrainian goods amounted to $\$ 39.48$ billion. US imports - $\$ 44.69$ billion Compared to 2017 , exports increased by $19.8 \%$, imports - by $27.8 \%$, and the negative balance of external trade in goods in 2018 amounted to $\$ 9.8$ billion. and almost doubled from the previous year ( $\$ 5.2$ billion). Accordingly, the import export coverage ratio in 2018 decreased to 0.83 compared to previous years ( 0.88 in 2017, 0.92 in 2016 and 1.01 in 2015).

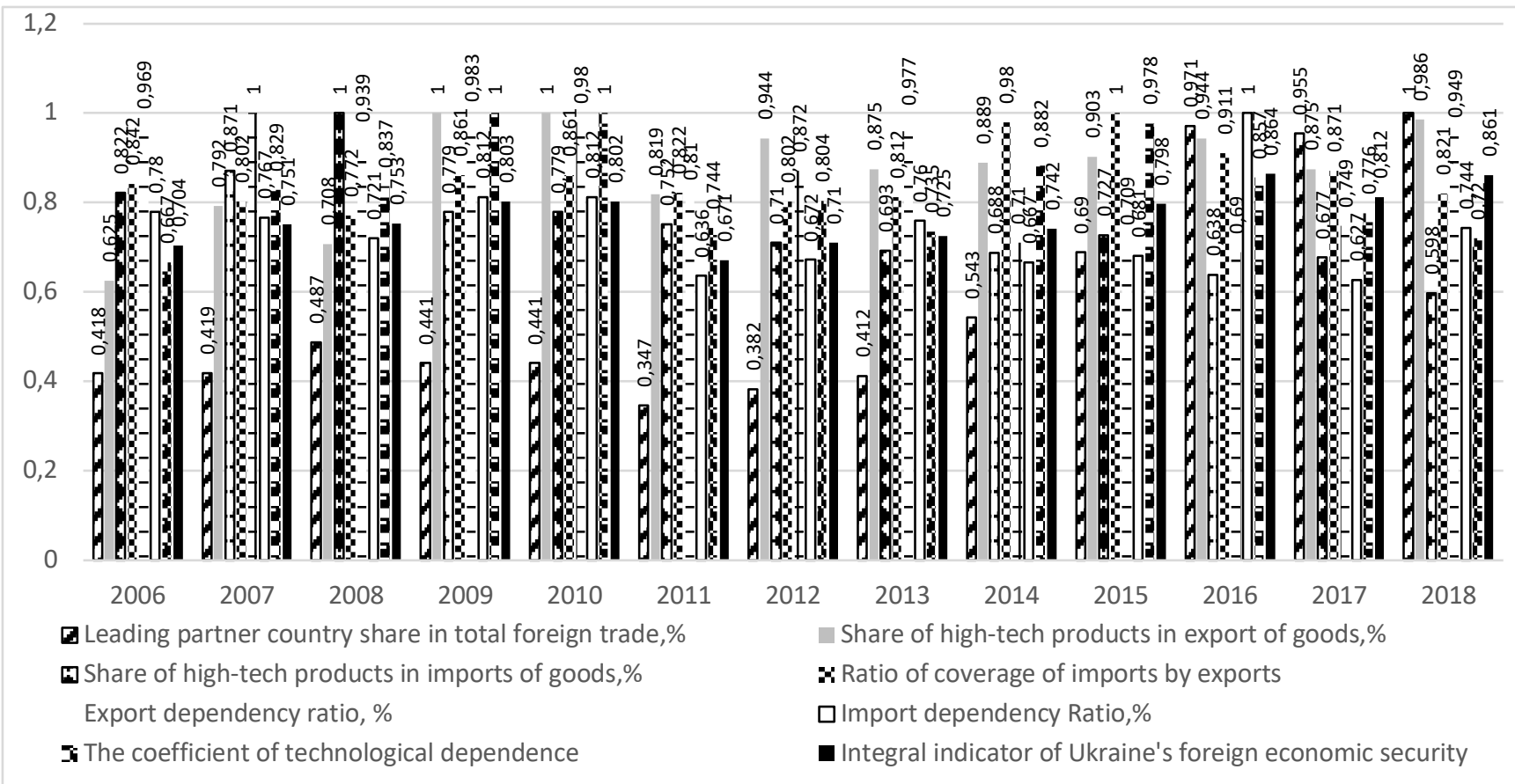

Fig. 1. Normalized values of indicators and integral index of external economic security of Ukraine (Babets, 2018; External, 2019)

Since 2017, the volume of external trade of Ukraine has been increasing after its sharp decrease in 2014-2015. Reduction of coal production by $22 \%$ and steel production by $17 \%$ led to a crisis in the metallurgical industry, whose share of production in the export structure of Ukraine in 2015 decreased to $24.8 \%$ (in 2014 this figure was $28.3 \%$ ). 
Other, equally important, reasons for the decline in exports were the imposition by the Russian Federation of trade restrictions on a number of Ukrainian goods: embargo (on vegetables and meat and dairy products); abolition of the RF regime of free trade with Ukraine (introduction of customs duties on goods, cars, chemical and metal products).

The crisis in relations with the largest trading partner highlights for Ukraine the need to diversify export supplies, which involves ensuring national interests in the context of strengthening economic independence and increasing the level of stability of the national economy. Expansion of opportunities to supply Ukrainian goods to the markets of developed countries is related to the implementation of a number of trade preferences within the framework of the Deep and Comprehensive Free Trade Area of EU with Ukraine the since 2016, as well as the ratification and entry into force of the Free Trade Area of Ukraine with Canada Agreement in 2017. .

However, Russia remains the leading partner country whose share in Ukraine's total external trade in goods tends to decrease (from 32.4\% in 2011 to $11.24 \%$ in 2018), which meets the criteria of economic security (does not exceed 30\%). At the same time, the rate of change of Ukraine's exports to Russia is lower than imports. In 2018, exports accounted for $92.8 \%$ of 2017 and imports $-112.3 \%$, respectively, and the negative external trade balance increased from \$ 3267.5 to $\$ 4438.6$ million (Krajiny, 2018). A positive sign of the geographical diversification of Ukraine's external trade is increasing in China's share to $9.4 \%$ in 2018 , although commodities are the dominant export structure.

In 2016, new opportunities were created for producers of Ukraine to enter the markets of the EU. In particular, Ukraine has a deep and comprehensive free trade zone with EU countries, which provides for the following trade preferences: the average rate of duty on Ukrainian goods was reduced from $4.9 \%$ to $0.5 \%$, the weighted average rate - from $5.0 \%$ to $2.6 \% ; 94.7 \%$ of the product range of industrial goods for deliveries to EU countries; in respect of $83.4 \%$ of food products and agricultural products of the EU countries, customs duties were abolished (while tariff quotas increased by $15.9 \%$ ); Ukrainian producers have been granted the right to supply the EU with seven of the fifteen categories of animal products and eight of the ten types of related products of animal origin (Sushko, 2016).

At the same time, the results of the sensitivity coefficient assessment prove that the integrated indicator of foreign economic security is the most sensitive to the dynamics of the leader's share in the total foreign trade turnover (0.276) (weight factor 0.235$)$, the coefficient of export dependence $(0.148)$ and 0.1 techlog goods $(0,151)(0,132)$. At the same time, the share of high-tech products of goods imports (0.080) (0.114), the coverage ratio of imports by exports $(0.117)(0.124)$, the coefficient of import dependence is $0.077(0.105)$, and the technological dependence ratio is $0.103(0.122)$.

Table 1. Results of Granger causality tests on the impact of major factors of external economic security on the quality of life index in Ukraine, 2006-2018

\begin{tabular}{|c|c|c|c|c|c|c|c|c|}
\hline \multicolumn{2}{|c|}{$\begin{array}{c}\text { Factor } \\
\text { indicator }\end{array}$} & $\begin{array}{l}\text { Leading partner } \\
\text { country share in } \\
\text { total external } \\
\text { trade, } \%\end{array}$ & $\begin{array}{l}\text { Share of } \\
\text { high-tech } \\
\text { products in } \\
\text { export of }\end{array}$ & $\begin{array}{l}\text { Share of } \\
\text { high-tech } \\
\text { products in } \\
\text { imports of }\end{array}$ & $\begin{array}{l}\text { Import- } \\
\text { to-export } \\
\text { coverage } \\
\text { ratio, } \%\end{array}$ & $\begin{array}{c}\text { Export } \\
\text { dependency } \\
\text { ratio, \% }\end{array}$ & $\begin{array}{c}\text { Import } \\
\text { Dependency } \\
\text { Ratio, \% }\end{array}$ & $\begin{array}{c}\text { The } \\
\text { coefficient of } \\
\text { technological } \\
\text { dependence }\end{array}$ \\
\hline \multirow{4}{*}{ } & 1 & $\begin{array}{c}0,325 \\
*\end{array}$ & $\begin{array}{c}0,859 \\
* *\end{array}$ & $-0,054$ & $\begin{array}{c}0,071 \\
*\end{array}$ & $\begin{array}{c}1,324 \\
*\end{array}$ & $-1,582$ & $-0,314$ \\
\hline & 2 & $\begin{array}{c}\mathbf{0 , 5 6 3} \\
*\end{array}$ & $\underset{* *}{0,948}$ & $-\mathbf{0 , 0 0 8}$ & $\begin{array}{c}0,829 \\
*\end{array}$ & $\underset{* *}{1,324}$ & $\begin{array}{c}-1,649 \\
* *\end{array}$ & $\begin{array}{c}\mathbf{- 0 , 9 3 8} \\
*\end{array}$ \\
\hline & 3 & $\begin{array}{c}\mathbf{- 0 , 6 9 4} \\
* *\end{array}$ & $\underset{* * *}{1,320}$ & $\begin{array}{c}-\mathbf{0 , 0 1 2} \\
*\end{array}$ & $\begin{array}{c}0,910 \\
*\end{array}$ & $\begin{array}{c}-1,462 \\
* *\end{array}$ & $\begin{array}{c}-1,678 \\
* *\end{array}$ & $\begin{array}{c}\mathbf{- 0 , 9 7 1} \\
* *\end{array}$ \\
\hline & 4 & $\underset{* *}{-1,243}$ & $\begin{array}{c}1,427 \\
* * *\end{array}$ & $\begin{array}{c}\mathbf{0 , 0 1 3} \\
* *\end{array}$ & $\begin{array}{c}\mathbf{0 , 9 5 5} \\
*\end{array}$ & $\begin{array}{c}-1,500 \\
*\end{array}$ & $\begin{array}{c}-1,840 \\
*\end{array}$ & $\begin{array}{c}-1,930 \\
* * *\end{array}$ \\
\hline
\end{tabular}


Source: Developed by authors

In our estimations, in 2018, the most significant factor was the decrease in the integral indicator of the reduction of trade with the Russian Federation. Accordingly, it can be argued that a 1\% decrease in the share of the leading partner country in total external trade turnover leads to increasing in the integral index by $0.276 \%$, all other things being equal.

At the same time, it should be emphasized that the results of calculating the impact of certain external economic security indicators on the quality of life index in Ukraine from 2006 to 2018 using the Granger cuasility test prove that, given the lag periods, the most attention should be paid to such indicators in the development of external economic policy. as share of high-tech products in export of goods (coefficient 1,427 in 4 period), coefficient of export dependence $(-1,500)$, coefficient of import dependence $(-1,840)$ and coefficient of technological dependence $(-1,930)$. In addition, the last three indicators, as we can see, are inversely proportional.

\section{Conclusions}

At the level of external threats caused by the deterioration of the world economy by changes and changes in the geopolitical situation, the level of foreign economic security of Ukraine is significantly affected by internal threats, risks and dangers associated with irrational structure of industrial production, namely the dominance of raw materials, European standards and reducing demand for high-tech goods.

Assessment of the dynamics and factors of the main indicators of Ukraine's foreign economic security in the short term indicates the presence of destructive trends associated with increasing technological and export dependence of Ukraine caused by low competitiveness in domestic and foreign markets and inefficient economic structure in general. At the same time, the absence or delay in the measures of public authorities to address these issues will threaten the loss of promising commodity markets, which are important to master given the reduction of trade with RF.

In the context of global crises exacerbation, we consider the need to strengthen the competitiveness of domestic producers as one of the main mechanisms for strengthening Ukraine's foreign economic security. At the same time, increasing the efficiency of the domestic market (its competitiveness) can be achieved on the basis of technical and technological modernization of economic entities, the development of import substitution, increasing the efficiency of the institutional basis of economic regulation. External competitiveness can be achieved on the basis of adaptation of quality parameters of Ukrainian goods to European technical standards, as well as the introduction of new technologies and production of products with high added value.

\section{References}

Babets I., Mokiy A., Fleychuk (2018) Strengthening ehternal economic security of Ukraine under the conditions of geopolitical transformations // International economic relations and prospects for national development: contemporary challenges and solutions: monograph / under the editorship of M.I. Fleychuk, U.A. Ganski, V.U. Kazlouski [and others]. Daugavpils: Daugava Print, 2018. - 368 p.

Baranovs'kij O. I. (2014) Filosofija bezpeki: monografija: u 2 t. / O. I. Baranovs'kij. - K.: UBS NBU, 2014. - T. 1: Osnovi ekonomichnoï i finansovoï bezpeki ekonomichnih agentiv. $-831 \mathrm{~s}$.

Eksport-import (2013) okremih vidiv tovariv za kraïnami svitu za sichen'-gruden' 2013 roku. URL: http://vvv.ukrstat.gov.ua.

Eksport-import (2016) okremih vidiv tovariv za kraïnami svitu za sichen'-veresen' 2016 roku. URL: http://vvv.ukrstat.gov.ua.

External (2019) Economic Activity of Ukraine. Official veb-site of the State Statistics Service of Ukraine // http://vvv.ukrstat.gov.ua 
Harazishvili Ju.M. (2007) Teoretichni osnovi sistemnogo modeljuvannja social'no-ekonomichnogo rozvitku Ukraïni: monografija / Ju.M. Harazishvili. - K.: Poligraf Konsalting, 2007. - 321 s.

Kasperovich Ju. V. (2019) Fiskal'na bezpeka derzhavi v umovah gibridnoï vijni// http://vvv.economy.in.ua/pdf/2_2019/13.pdf

Kibitkin A.I., Skotarenko O.V. Jekonometricheskie metody ocenki chuvstvitel'nosti jekonomicheskoj sistemy. Vestnik MGTU. 2010. - \#1. S. 22-26.

Kozachenko G. V., Illiashenko O. V. Matkovskiy A. V. (2019) Factors of financial and economical security of ehternal economic activity in Ukraine in conteht of globalization challenges. Financial \& Credit Activity: Problems of Theory \& Practice. 2019, Vol. 1 Issue 28, p. 373-382.

Krajiny za tovarnoju strukturoju zovnishn'oï torgivli Ukraïni u 2018 r. URL (2018): http://vvv.ukrstat.gov.ua/operativ/operativ2018/zd/tsztt/tsztt_u/tsztt1218_u.htm.

Oleksandr Vlasiuk, Olga Iljash, Vieslav Olszevski, Magdalena Osinska, Volodymyr Voloshyn (2016). System transformations of the national economy: challenges and ehpectations - Collective monograph edited by Oleksandr Vlasiuk, Olga Iljash, Vieslav Olszevski, Magdalena Osinska, Volodymyr Voloshyn. - University of Economy Publishing House, Bydgoszcz, Poland, 2016. - Vol. 1. -242 p.

Parahons'kij, G. M. Javors'ka, O. O. Reznikova (2013) Mizhnarodne bezpekove seredovishhe: vikliki i zagrozi nacional'nij bezpeci Ukraïni. B. O. za red. K. A. Kononenka. K. : NISD, 2013. - 56 s.

Poyda-Nosyk N. N.(2017) Financial security of Ukraine in conditions of European integration// Ekonomika ta upravlinnja nacional'nim gospodarstvom // Naukovij visnik Polissja \# 1 (9), ch. 1, 2017.

Pro zatverdzhennja Metodiki rozrahunku rivnja ekonomichnoï bezpeki Ukraïni. Nakaz Ministerstva ekonomiki Ukraïni vid 02 bereznja 2007 r. (2007) \# 60 URL: http://vvv.ehpert-ua.info/document/archivepa/lav5hvjaoi/indeh.htm/.

Sushko O. (2016) Vprovadzhujuchi Ugodu pro asociaciju Ukraïna - ES: pershi uroki, naslidki, praktiki vikoristannja: Analitichna dopovid' / [O. Sushko, R. Horol's'kij, V. Movchan, O. Miroshnichenko]; za red. Sushka O.V. K.: Institut Evro - Atlantichnogo Spivrobitnictva, 2016. - $41 \mathrm{s.}$

Venckovs'kij D.Ju. (2015) Zovnishn'oekonomichna bezpeka Ukraïni: stan ta naprjami zabezpechennja // Strategichni prioriteti. 2015. \#3. S. 56-63.

Zovnishnja torgivlja Ukraïni z kraïnami CS (2019). URL: http://vvv.ukrstat.gov.ua. 